\title{
An Analysis of Training Objectives of Agricultural Foreign Trade Talented Translators
}

\author{
Qi Xiong, Yun-Fei Ma* \\ Tianjin Agricultural University, No.22, Jinjing Road, Tianjin, P.R.China \\ esther054000@163.com \\ ${ }^{*}$ Corresponding author
}

\begin{abstract}
Keywords: Agriculture, Foreign trade talented translators, An analysis of training objectives.
\end{abstract}
\begin{abstract}
Agriculture is the fundamental of a country. The stability and prosperity of the whole country depend much on the development of agriculture, the construction of the countryside and the happiness of the farmers. With the deepening of reform and opening up and acceleration of economic globalization, the development of agriculture in China also enters the process of modernization. In this process, the expansion of foreign trade can not only promote the economy, but also improve the income level and life quality of Chinese people, especially the farmers - the vast majority of the population. Now China is lack of agriculture trade translators to ensure the smooth progress of agriculture products trade activities, and it is necessary to analyze the required skills and training objectives of agricultural foreign trade talented translators.

Agriculture is the basic industry of China, and agriculture has raised more than one billion Chinese people. The vast majority of China's population is in the rural areas, and the living standard of farmers is related to the development of nation and stability of society. For the comprehensive development of modern agriculture, the substantial increase in farmers' income, the extensive construction of new countryside, modern China is making unremitting efforts. In this process, china's agricultural products trade has got sustained and rapid development and China has maintained a position of super power of world's agricultural trade. The rapid development of agricultural products trade plays a more and more important role in regulating the domestic market surplus and deficiency, optimizing rural and agricultural structure, promoting the increase of farmers' income, and maintaining a steady and rapid development of the national economy [1]. Because of this, it is particularly critical to ensure successful agricultural products import and export; in the meantime the language barrier should be overcome. Given that English is the universal language, to overcome the obstacles in the communication between Chinese and English is the main purpose. At present, the cultivation of agricultural foreign trade talented translators is far from professional and lacks systematic methods, and the training objectives is not clear. This thesis will analyze the objectives of training agricultural foreign trade translation talents.
\end{abstract}

\section{To Build Solid Agricultural English Foundation}

English for agriculture in fact refers to English for agricultural science and technology, and it is professional English used for agricultural science and technology. That is to say, English for agriculture is a branch of science and technology English [2]. The study and research of English for agriculture are professional, while at present, the number of China's colleges and universities with majors of agricultural English is small and the teaching quality of them is limited. The majors of agricultural English are mostly marginalized and using general English teaching patterns. It is difficult to cultivate professional talents of English for agriculture. Therefore, training institutions should help to make up for the lack of teaching courses for agricultural English, which is caused by the emphasis on cultivating inter-disciplinary talents by universities and colleges.

As a branch of English for science and technology, English for agriculture has the common features of English for science and technology. They are logical, strongly objective, rigorous and standard. Due to the particularity of agricultural science, agricultural English also has some unique characteristics, such as the connotative meaning of words, the conversion of parts of speech and 
omission of personal pronouns. It is unavoidable to translate those words in the process of translating English for agriculture. In order to make better communication, translators must deepen the study of characteristics and application of English for agriculture.

When translating words, translators should pay attention to the word formations, such as roots (manure), composite (borrowing), and phrase type (cooperative farm). When translating sentences, translators should pay attention to the translation of long and complex ones.

During the process of cultivating agricultural foreign trade translation talents, features and translation skills of English for agriculture should be taught to make the talents be familiar with and flexible use of the common expressions of English for agriculture, and then lay a solid foundation for agricultural foreign trade translation.

\section{To be Proficient in Business English}

Agricultural foreign trade is not just about the buying and selling of agricultural products in the international market, but also including international agricultural exchanges and cooperation. Business English is also not just doing business in English. To learn business English is at the same time to learn language, business knowledge, business skills, and complemented by a large number of commercial knowledge and skills related to business management, trade, legal, accounting and so on. Agricultural foreign trade and business English can fit each other well because they both have broad concepts. In the training of agricultural foreign trade translation talents, the key directions are practice of international trade and exhibition English.

\section{Practice of International Trade}

This direction is to train higher applied talents with necessary basic theoretical knowledge and professional knowledge of business English, mature business capability and English application ability to engage in business and secretary profession. The core training program is constructed by three skills modules: English language competence, business operation skills and computer application technology. Agricultural foreign trade translators should not only have strong language skills, but also know foreign trade and computer, so as to compensate for the generally low cultural quality of peasants in China.

\section{Exhibition English}

This direction is to train practical high-level professionals with the basic theory and knowledge of the exhibition design and advertising, possessing the capability of exhibition design and planning as well as creation and design with computer. After the training they can be engaged in exhibition organization and planning, exhibition translation, coordination and services, management of international affairs or domestic business.

These professional talents can play a crucial role in various units and positions, they can be engaged in international trade, import and business negotiation, translation, foreign secretary and management work in international business companies, foreign-funded enterprises, co-operative ventures, private enterprises, financial institutions, Chinese branch company of multinational company, overseas Chinese companies, foreign institutions, government, administrative units. They are also suitable for all foreign trade companies, shopping malls, hotels, enterprises and institutions. After training, agricultural foreign trade personnel can be engaged in translation and business negotiation work in agricultural products import and export enterprises and have wide development prospects.

Agricultural foreign trade translators must be proficient in Business English to guarantee the least mistakes in the process of foreign trade to help maximize benefits and minimize losses for enterprises and the nation.

\section{Higher Translation Level}

Having achieved the above two goals lays a foundation for training a good agricultural foreign 
trade translators. Agricultural foreign trade translators' ace in the hole should be the outstanding ability of translation. The improvement of translation ability is based on the theory learning and depends on the amount of training. Translators should take part in practice and try to get practice opportunities in enterprises and at the same time go to the countryside to get fully informed of the needs of farmers.

The translation of English terms in agriculture has been the difficulty and focus in English for agriculture translation, and agricultural English terms can be divided into agricultural specialized terms and agricultural quasi technical terms. The former, according to the word formation method, can be divided into word terms, derived terms, and compound terms. In word terms and compound terms, most of word type compound terms and hyphen compound terms have conventional translation which can be easily obtained through searching related professional dictionaries. For example, to translate derived terms such as "Agrobiology" and "photothesis", translators can firstly apply structural analysis, and then translate them according to the context. The translation of phrase type composite terms always uses positive translation method. For example, dairy industry, market gardening. In terms of translation of agricultural quasi technical terms, translators should choose their professional interpretation in the field of agriculture. Before the translating, translators should know the characteristics of agricultural English terms and possess professional agricultural knowledge and be able to flexibly employ translation skills [3].

Translation of sentences in English for agriculture is different from that of "general English". The sentences in English for agriculture have many special characteristics such as lots of long and complex sentences, the extensive use of the term structure, widely use of passive sentences and post modifier and so on. The translation of those sentences should be flexible but firstly achieve "faithfulness and expressiveness". Please refer to the sentence in the following figure as an example.

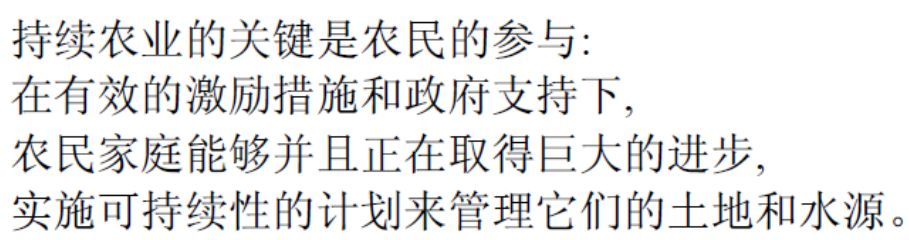

Fig. 1

Translation: Farmer involvement is the key to sustainable agriculture. Given the right incentives and government support, farm families can and are significant progress towards managing their land and water sustainability [4].

In this sentence, the translation of the non-restrictive verbs is flexible and accurate, and is worth to be learned. The agricultural foreign trade translators often translate agricultural products import and export documents and instructions, which requires objectivity and accuracy. While during the process of foreign business interpreting is in the priority need. Interpreting itself is a demanding and difficult behavior. When it is involved with the professional field, it becomes much harder. In the training process MII (multiple interactive immersed) teaching method in business English can be applied: M (Multiple), requiring multiple personalized curriculum design and providing more choices for students; it focuses on the full range of training so that students not only get good improvement in the level of English, but also get more comprehensive and in-depth understanding of China's agriculture. The first "I" stands for "interactive", requiring small class teaching, focusing on learning effect, good atmosphere in the classroom, and full range of interactive forms between teachers and students (free to ask questions, discuss in groups, personal speech, interactive games), and join competition, rewards, punishments and other links to the teaching process. The second "I" refers to "Immersed", requiring teaching in English completely; create a good learning environment for students to improve their English level, especially the skill of interpretation. Using this method to cultivate agricultural foreign trade translators can rapidly improve their English and translation skill. In the daily life translators should keep on accumulating and pay attention to national agricultural policy trends and agricultural trade changes timely. 


\section{Summary}

Agriculture has become a key problem for China and the world as a result of the continuing growth of population and the acceleration of resource consumption. As a populous country, China should develop modern agriculture and agricultural foreign trade, which can optimize the domestic market of agricultural products and increase the income of farmers. In this process, there is a huge gap in professional translation talents. To output more related translation talents, this paper analyzes the objectives of training related foreign trade translation personnel. They must have a solid foundation knowledge of English for agriculture, and are familiar with fixed expressions of agricultural science and technique terminology; they also need to master Business English to earn more benefit for enterprises and nation; the last and the most important, they must have a high level translation capability, and can improve the level and ability of translating by using the MII method to make a contribution to the development of China's agriculture.

\section{Acknowledgements}

This research was financially supported by China Agricultural Association funded project: "research on the strategy of universities agricultural think tank construction from the international perspective" (PCE1401); the 2014 Tianjin Municipal university students innovation and venture training programs: Tianjin university students' foreign language training center "serving for agriculture, rural areas, and farmers" (201410061246); the National Educational Science "the $12^{\text {th }}$ Five Year Plan" 2014 key project of Ministry of Education: "research and formulation of Common Chinese Framework of Reference for English level” (DIA140304).

\section{References}

[1] The Agricultural Trade Promotion Center of the Ministry of Agriculture. Research on Agricultural Trade. Beijing: Agricultural Press, (2009)134-137.

[2] Wang Qingwei. The language features and translation methods of agricultural English. Journal of Central China Agricultural University, Vol.4 (2009), p. 42.

[3] Zhang Ying Mei. Research on the language features and translation strategies of Agricultural English. Hunan Agricultural Machinery, Vol.9 (2011), p. 26-28.

[4] Peng Jun. The characteristics and translation of agricultural English. Education Online, Vol.2 (2013), p. 91-93. 